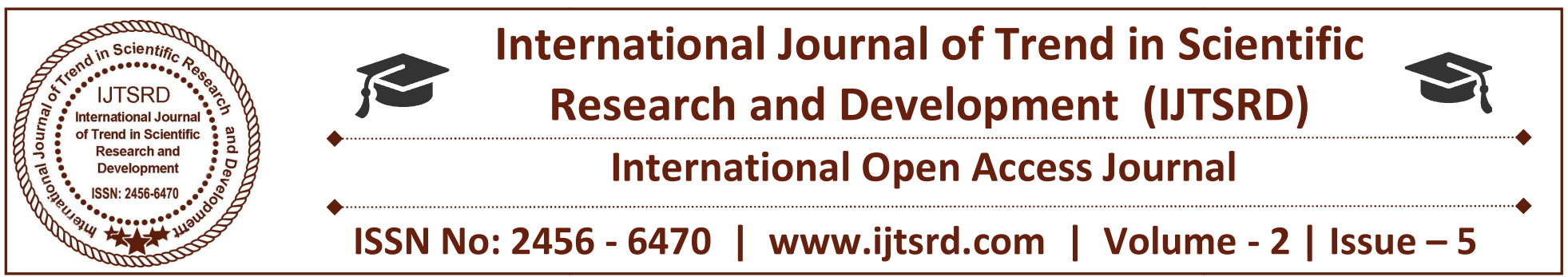

\title{
Whether Section 377 of IPC Voilates the Fundamental Rights
}

\author{
Ashutosh Gupta \\ B.A., L.L.B. (Hons) - II Sem., Indore Institute of Law, Affiliated To DAVV and BCI, \\ Indore, Madhya Pradesh, India
}

\begin{abstract}
This paper make much of the result of the case Naz Foundation in which it decriminalises homosexuality, but the main question is that the continuing problematic legal labelling of it as an activity that contravenes the order of nature. The term such as the 'order of nature' in the context of the sexual preference are inherently indeterminate, vague and arbitrary and are therefore likely to the contravene Article 14, 15, and 21 of Indian constitution. The Naz court endores a line of sec. 377 of IPC cases that embody a prudish Victorian morality, under which only ' protective' sex is comes under the 'natural act'.
\end{abstract}

According to this logic of Naz Foundation, even use the contraceptive during the sex would count as the unnatural, as the absurd result, given that the India suffers a population explosion problem. In any case, it is not the place of the states to regulate such private Acts that cause no palpable harms.

This paper explores the all hidden facts of the section 377 of IPC and as well as all the parameters of Article 14,15 ,and 21 of constitution of India and argues that is difficult to locate any intelligible differentia between the term 'natural' and 'unnatural'. The court did not adopt the more 'natural' line of the argument above and strike down section 377 as a whole, as it may have feared the resulting decriminalisation of problematic sexual activities such as paedophilia and bestiality.

\section{INTRODUCTION}

Animals like Elephant do it, Birds like penguins do it, and even butterflies do it. The peoples of ancient Greeks practiced it freely and also the ancient Indians did it. As the current of the occurrence of exclusive homosexuality range from one to twenty percent of the population. Yet, in many societies from the ancient age to the present age the homosexuality comes under the 'unnatural act'. bet in the other hand some societies accepts the homosexuality relationship from the ancient age to the modern age. In one hand some societies demand the separate laws for the homosexual relationship but in other hand some societies repress it through the law and prescribed it under the penalty of death.

To build the truly democratic and plural India, we must collectively fight against the laws and policies that abuse human rights and limit fundamental freedom.

Let us always remember the truth expressed in the opening articles of the universal declaration of Human rights that "All person are born free and equal in dignity and rights, everyone is entitled to all the rights and freedoms set forth in this declaration, without distinction of any kind."

We concerned Indian citizen, support the overturning of the section 377 of IPC. The IPC is a colonial-era law which was dated in 1860, and it punitively criminalizes the romantic love and private consensual sexual acts between the adults and same sex.

The section of the IPC was creation of the British, and come into force in 1860, this law was applicable in England also but in the 1967 by passing the Sexual Offence Act, England decriminalized homosexuality back.

\section{Section 377 of IPC 1860}

Section 377 of Indian Penal Code defines the 'Unnatural Offence' and According to it "whoever 
voluntarily has carnal intercourse against the order of nature with any man, woman or animal, shall be punished with the imprisonment for life, or with imprisonment of either description for a term which may extend to ten years and shall also be liable to fine".

\section{Order of Nature}

In 2009 the Delhi High court struck down the section 377 of Indian Penal Code 1860 and legalized the homosexuality.

Chief Justice Mr. AP Shah had said, "we declare that section 377 of IPC, insofar it criminalizes consensual sexual acts of adults in private, is violative of Article 14,15 and 21 of the constitution."

After the order an appeal against the Delhi High Court was being heard by the Supreme Court.

The Additional Solicitor General of India Mr. PP Malhotra said in the Supreme Court, "Gay sex is highly immoral and against social order and there is high chance of spreading of diseases like AIDS through such acts."

The court wanted to know the meaning of 'order of nature' from the Government while discussing the issues. It asked "who is the expert to defined the term 'order of nature', more so in relation to carnal intercourse? Meaning of word has never been constant. Test-tube babies, surrogate mothers-are they in the order of nature."

And other questions arises that-

1. Is contraception is against the order of nature?

2. Is consensual intercourse between a man and woman involving oral sex and anal sex against the order of nature?

3. Is talking dirty during sex against the order of nature?

\section{Violation of Rights of Citizens}

According to the 13(2) of the Indian constitution it is defined that "The state shall not make any law which take away or abridge the rights conferred by this part and any law made in contravention of this clause shall, to the extent of the contravention, be void" so, according to the constitutional provision section 377 of IPC violates some fundamental rights of the citizen of India.
Section 377 of IPC is the violation of the Article 14

Article 14 of Indian constitution defined about the equality before the law, and it is defined that "The State shall not deny to any person equality before the law or the equal protection of the laws within the territory of India."

Article 14 also focus on the doctrine of intelligible differentia, according to the doctrine of intelligible differentia there should be clear nexus between the enacted provisions or act and its objective as for what purpose they have been enacted. The same makes it clear that a law enacted by legislature must be clear and must be rational.

The Supreme Court had held that a statute is void for vagueness if its prohibition is not clearly defined. The rationale for this that the provisions enacted should be clear so that persons affected know the true intention. ${ }^{1}$

Further the Supreme Court had held that where a law does not offer a clear construction and the persons applying it are in a boundless sea of uncertainties and the law prima facie takes away a guaranteed freedom, the law must be held to offend the constitution. ${ }^{2}$

Section $377 \mid$ of IPC creates an arbitrary and unreasonable classification between the penile-veginal and penile-non-veginal sexual acts in the name of procreative sex and non-procreative sex and hence violation of Article 14 guarantee of equal protection before and under the laws.

\section{Doctrine of Vagueness}

The void for vagueness doctrine or the doctrine of vagueness argues that a law can't be enforced if the law is so vague or confusing that the average person could not figure out what is being prohibited or what the penalties are for breaking that law. Vagueness is generally considered to be a due process issue, because a law that is too vague to understand or very confusing and does not provide adequate notice to people that a certain behavior is required or is unacceptable.

Vagueness is an argument typically used in criminal cases, when a law that is supposed to prohibit a certain behavior is too vague or confusing for people to understand what behavior they're supposed to

${ }^{1}$ Kartar Singh v. State of Punjab(1994) 3 SCC 569.

${ }^{2}$ K.A Abbas v. Union of India AIR 1971 SC 481. 
avoid, on penalty of being charged with or convicted of a crime. However, laws that cover civil matters are occasionally challenged for vagueness as well.

The doctrine of vagueness or vagueness doctrine rests on due process clause fifth and fourteenth amendment of the U. S constitution.

Although In India the void for vagueness doctrine is accepted, and although the phrases 'unnatural' offences or 'against the order of nature' are indeterminate and susceptible to differing interpretations, it would still be looking very difficult to convince an Indian court that Section 377 is vague, since the threshold is fairly high. Several decisions stand testimony to the propensity of the Indian judiciary to construe vague laws in a manner as to render it effective and operative. It also bears noting that Section 377 is, at present, the only provision which deals with problematic sexual activities such as bestiality and paedophilia.

Any argument premised on vagueness would necessarily have to strike at the root of Section 377 and decriminalise the above activities, which is given in section 377. For that reason, any Court is likely to be hesitant in striking down the entirely of Section377. This also explains that why the petitioners in Naz foundation casedid not argue that Section 377 should be struck down as a whole, and instead limited themselves top leading that sexual intercourse between two consenting same sex adults in privacy be removed from the ambit of the penal provision. ${ }^{3}$

But in 2015, In Shreya Singhal vs Union of India, At one time this court seemed to suggest that the doctrine of vagueness was not a part of Constitutional law of India. That was dispelled in no uncertain terms in $\mathrm{K}$. A Abbas vs The Union of India \& Another. ${ }^{4}$

However, notwithstanding the difficulty in establishing an Article 14 violation on the grounds of vagueness or arbitrariness, the challenge under the traditional 'reasonable classification' pillar underlying Article 14 is a strong one.

\footnotetext{
${ }^{3}$ Durga Das Basu, Shorter Constitution of India, Wadhwa And Co. (2006); pp. 1651

${ }^{4}[1971] 2$ S.C.R. 446.
}

\section{Absence of Rational Nexus}

In section 377 of IPC there should be the absence of rational nexus. It is well settled that, in order to pass the test of reasonable classification required by Article 14 of the Constitution, the classification must fulfill two criteria:

1. The classification must be founded on an intelligible differentia.

2. The differentia must have a rational nexus to the objective sought to be achieved by the act in question. In short, there must be a causal connection between the basis of classification and object of the statute under consideration.

Using this principles, there is a questions whether sexual intercourse is classified into two parts that is 'natural' and 'unnatural' forms is an intelligible one. And more important is that, whether it bears a rational nexus to the object underlying Section 377.

\section{Section 377 is violation of Article 15}

Article 15 (1) of the Indian Constitution provides that, "The State shall not discriminate against any citizen on grounds only of religion, race, caste, sex, and place of birth or any of them.

The expression "sex" is fluid and is not a statical concept. There should be no restriction on biological sex of male and female. It is not an essential condition that the law expressly makes the prohibited ground for the basis of classification.

As held by the Supreme Court, "The Court's are always had to interpret any law by the way of 'schematic and teleological' method of interpretation. All it means is that the judges do not go by the literal meaning of the words or by the grammatical structure of the sentence. They go by the design of purpose which lies behind it. ${ }^{5}$

Thus, in introduce situation the expression "Sex" has a more extensive significance and it incorporates sexual introduction, which incorporates gay individuals. The denial of separation on the ground of sex is expected to disallow the connection of standard personal conduct standard to sexual orientation. The reason basic the crucial appropriate against sex segregation is to avert conduct that treats individuals contrastingly for reason of not being in similarity with

${ }^{5}$ Fuzlunbi v. K. Khader Vali, AIR 1980 SC 1730. 
speculations concerning "ordinary" sexual orientation parts.

In the present time, area 377 criminalizes the demonstrations of gay individuals or the gay intercourse. In spite of the fact that facially unbiased, the essential protest and the immediate and unavoidable impact is the preclusion of sexual acts between gay in light of their sexual introduction, It is an established position of law that if the effect of a State action is to infringe a fundamental right and that effect is brought about by a distinction based on a prohibited ground (e.g. sex, race, etc), it would constitute discrimination on the prohibited ground, however laudable the object of the State action may be. ${ }^{6}$

In the case of the Punjab Province v. Daulat Singh", the SC held that, "It is enough for a law to be struck down as being discriminatory on a prohibited ground that the law operates so that its effect in some cases is that some persons are discriminated only on the basis of a prohibited ground."

In the present time, the provision of Indian Penal Code in section 377 infringed the fundamental rights of a person. And in the Indian Constitution it is clearly given that the law cannot discriminate any people on the grounds of race, caste, sex etc. and according to the law the homosexual people also have the right to not to discriminate on the grounds of sex.

\section{Section 377 is violation of Article 21}

Article 21, Indian Constitution, conforms on every person the fundamental right to life and person liberty which has became an inexhaustible source for many other lives. These rights are as much available to citizen as to foreigner. ${ }^{8}$ And this article has been given paramount position by the hon'ble Supreme Court. Homosexual people are also included under article 21 as they are also human being. The Supreme Court in the case of Kharak singh v.

\footnotetext{
${ }^{6}$ State of Bombay v. Bombay Education Society, [1955] SCR 568.
}

${ }^{7}$ AIR 1946 PC 66.

${ }^{8}$ National Human Right Commission v. State of Arunachal

Pradesh, (1996) 1 SCC 742.
State of Uttar Pradesh, ${ }^{9}$ it has been held that right to life is most fundamental rights of all. The word 'life' in the article 21 does not confine itself mere animal existence, but the word 'life' includes wider meaning than mere an animal existence in the society. The inhabitation against its deprivation extended to all those limbs and faculties by life is enjoyed. The provision also equally prohibits the mutilation of the body by amputating off any part of the body, or any other organ through which the soul communicates with outer world. And sexual orientation not being outer part of the body but if a person deprived of being having sexual orientation this also amount to mutilation of the body.

In Bandhua Mukti Morcha V. Union of India, ${ }^{10}$ the honorable court held that "There are minimum human requirements which exist in order to enable a person to live with human dignity, and no state has right to take away action which will deprive a person of the enjoyment of this basic essential"

The basic essentials of a person's life can be named as follows:

$>$ Privacy

$>$ Human Dignity

$>$ Health

\section{Right to Privacy}

The privacy is that "area of a man's life which in any given circumstances a reasonable man with an understanding of the legitimate needs of the community would think it wrong to invade" Although constitution of India is like American constitution it does not guarantee right to privacy explicitly, yet we may say that right to privacy is implicit in Article 21 of the Constitution. A question arose for the first time in Kharak Singh v. State of U.P. ${ }^{11}$ Whether right to privacy is included in the right to personal liberty. Justice Subba Rao, speaking for minority, held that "right to privacy though not expressly declared in our constitution, is an essential ingredient of the personal liberty."

In the case of R. Rajagopalan v. State of Tamil $\mathrm{Nadu}^{12}$

${ }^{9}$ AIR 1963 SC 1295.

${ }^{10}$ AIR 1984 SC 802.

${ }^{11}$ Supra 9

${ }^{12}(1994) 6$ SCC 632. 
, the Supreme Court held that "it is right to be let alone and a citizen has the right to safeguard the privacy of his own, his family, marriage, protection, motherhood, child-bearing and education among other matter. No one can punish anything concerning the above matter without his consent whether truthful or otherwise and whether laudatory or critical." To the extent this issue is concerned, the reprimanded area unquestionably abuses the privilege to security ensured by the Constitution as it peeps into the places of individuals without their assent and still rebuffs them for their private issues.

For the most part, criminal arrangements are advocated on the understructure that they avoid hurt. In the domain of sex, regardless of whether hurt is caused is subject to assent. Where assent is given, a man isn't hurt and the self-dominance falls when inside the domain of individual self-governance that does not require policing by the State. Just where there is no assent is criminal authorizing defended?

It is in addition perceived that at the unit of the privilege to protection are those issues identified with one's private life and close connections. This circle of private closeness and self-sufficiency must enjoy people to create human connections without impedance from the outside nation or from the State. The privilege to protection is subsequently commenced on the suggestion that there exists a zone of security made by different basic rights into which the State can't barge in.

It is presented that sexual affections between people, regardless of whether gay or hetero, fall inside the ensured zone of protection. Section 377, by criminalizing unrepeatable consensual sexual acts, disregards the privilege to security.

Consequently, the decried area undeniably disregards appropriate to protection of the general population concerned and subsequently damages ideal to life and individual freedom ensured under Constitution of India.

\section{Human Dignity}

The case law also recognizes that the right to privacy is derived from, and intimately related to, the right of each person to dignity.
In Gobind v. State of Madhya Pradesh, ${ }^{13}$ the honorable Supreme Court has held: "Privacy-dignity claims deserve to be examined with care and to be denied only when an important countervailing interest is shown to be superior".

Poise, at that point, is worried about the privileges of an individual, and is connected to individual selfacknowledgment and self-governance. In the event that the privilege to protection gets from a regard for human nobility or dignity, it should likewise be an individualistic right, collecting to a man wherever he might be.

In this matter, section 377 of IPC affects dignity of a person as it exposes a person of his sexual orientation and also punishes him and sends him to prison which violates his right to live a dignified life. The Supreme Court has held that "every act that offends against or impairs human dignity would constitute deprivation pro tanto of this right to live and it would have to be in accordance with reasonable, fair and just procedure established by law which stands the test of other fundamental rights." 14 In the present case, section 377 , by criminalizing private, consensual sex between adults, offends against and impairs the expression of the human self of sexuality, more particularly men who have sex with men, and thus violates their right to live with dignity. Further, it does not stand the test of other fundamental rights. As has been shown above, section 377 is not reasonable, fair or just law according to conditions of article 14, 15(1)

\section{Right to Health}

These gay populaces are for the most part hesitant to uncover same sex conduct because of the dread of law implementation organizations, keeping a vast area imperceptible and inaccessible and pushing the disease underground, making it troublesome for Health Ministry to get to them. Authorities of UNAIDS say there is no information on the gay populace in India as gathering such data is illicit under Section 377. It gives clear thought of issue made by the reviled area that as a result of this segment, even UN authorities are not ready to avoid AIDS in India.

\footnotetext{
${ }^{13}(1975) 2$ SCC 148.

${ }^{14}$ Francis Coralie Mullin v. Administrator, Union Territory of Delhi, (1981) 1 SCC 608.
} 
Section 377 is violates the Basic Features of the Constitution of India

Section 377 of IPC denies the targets revered in the preface in particular: Justice, Liberty and Equality to gay individuals. These targets constitute the Basic Feature of the Constitution. Further, it denies fairness and equivalent security and makes disparity and subsequently it is clear infringement of Basic Feature of the Constitution and thus subject to be meddled with by the court.

\section{Naz foundation case}

In 2001, Naz Foundation filed an open intrigue suit under the steady gaze of the Delhi High Court testing the sacred legitimacy of Section 377 of the Indian Penal Code, 1860. The Delhi High Court rejected the Petition in 2004 holding that the inquiry was just scholarly and there did not lay a reason for activity. An ensuing audit appeal to be additionally rejected. Naz Foundation at that point recorded a Special Leave Petition under the steady gaze of the Supreme Court of India testing the requests of the Delhi High Court. On 03.02.2006, the Supreme Court put aside the request the Delhi High Court and remanded the case back to the Delhi High Court for a choice on the benefits of the case. In second July 2009, the Delhi High Court dissolved the law that criminalizes grownup gay relations, finishing a nine year old fight in court for gay rights. Again On twentieth July, 2009 one Mr. Suresh Kumar Koushal files a Petition in the Supreme Court against the Delhi High Court judgment which decriminalized consensual sex between grown-ups under Section 377.

\section{Judgment}

The case came up for hearing before a seat involving Chief Justice Ajit Prakash Shah and Justice S. Muralidhar, and the judgment was conveyed on 2 July 2009. The Court found the rights to pride and protection inside the privilege to life and freedom ensured by Article 21 (under the fundamental Right to Freedom charter) of the Constitution, and held that criminalization of consensual gay sex abused these rights.

The Court additionally held that Section 377 outrages the assurance of equity revered in Article 14 (under the fundamental Right to Equality charter) of the
Constitution, since it makes a nonsensical order and targets gay people as a class. Public animus and appall towards a specific social gathering or powerless minority, it held, is definitely not a substantial ground for arrangement under Article 14. Article 15 of the Constitution restricts separation in light of specific attributes, including sex. The Court held that "sex" incorporates natural sex as well as sexual introduction, and subsequently segregation on the ground of sexual introduction isn't allowable under Article 15. The Court likewise noticed that the privilege to life under Article 21 incorporates the privilege to wellbeing, and reasoned that Section 377 is a hindrance to general wellbeing since it hinders HIV aversion endeavors.

The Court did not strike down Section 377 in general. The area was proclaimed unlawful insofar it criminalizes consensual sexual demonstrations of grown-ups in private. The judgment keeps flawless the arrangement seeing that it applies to nonconsensual non-vaginal intercourse and intercourse with minors. The court expressed that the judgment would hold until Parliament chose to correct the law.

\section{Conclusion}

Section 377 of Indian Penal Code which is come into enforced on 1860 and that was the time of the British rule in India and British parliament passed a law on 1860 and the law was enforced in India and section 377 of Indian Penal Code defines that " whoever voluntarily has carnal intercourse against the order of nature with any man, woman or animal, shall be punished with imprisonment for lifetime, or with imprisonment of either description for a term which may extends to ten years and shall also be liable to fine." and this part of the Indian Penal Code violates the fundamental rights of person, as given in this part that the homosexual intercourse or the consensual intercourse between two same gender is comes under the unnatural offence and it is punishable under the section 377 of Indian Penal Code 1860 and it also violates the fundamental rights like Article 14,15 and 21 of Indian Constitution and the violated rights are "right of equality before law or right to equality", "right to prohibition of discrimination on the grounds of sex" and "right to life, right to health and right to privacy." 